\title{
Perspectives of conservation of pond-breeding frogs (focusing on the Nagoya Daruma pond frog) in rice paddy areas in Japan
}

\author{
Risa Naito \\ Graduate School of Global Environmental Studies, Kyoto University, Yoshida- \\ Honmachi Sakyo-ku, Kyoto, 606-8501 Japan
水田地帯におけるカエル類（特にナゴヤダルマガエル） の保全について

内藤 梨沙

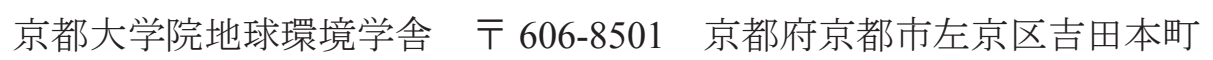

\begin{abstract}
It has been two decades since the crisis of amphibians gathered attentions and triggered the intensifications of research on the reasons of declines and ecology of amphibians. The reasons for declines differ place to place and species to species but the main threats are the loss of wetland, habitat fragmentation and environmental pollution. In Japan, since the large part of natural wetlands has been lost, rice paddies and related areas have played important roles as substitute habitat for wetland species and supported rich indigenous ecosystems. The modernization of agriculture and increase of abandonment of farming however drastically changed these environments. Anuran species, especially pond-breeding frogs, are very common and representative of rice paddy ecosystems. Most of frogs are sensitive to environmental pollution and require both aquatic and terrestrial habitats to complete life cycle, they are considered bio-indicator of environmental changes of rice paddy area. For this paper, I focused on an endangered pond-breeding frog, the Nagoya Daruma pond frog (Anura: Ranidae, Pelophylax porosa brevipoda Ito, 1941), because its life history is closely linked to rice paddy areas. Because most of its natural habitat has been lost, and currently no population in natural habitat is known, for the conservation of the frog, it is vital to study the ecology in the areas. The main threats for the species are changes in yearly water management in rice paddies, improvements of drainage by agricultural modernization and hybridization between Pelophylax porosa nigromaculata. In this paper, I reviewed the situations of amphibians, the relationship between rice paddy area and frogs, conservation of frogs in agroecosystem and life history and ecology of $P$. p. brevipoda for discussing conservation of frogs in rice paddy area especially $P . p$. brevipoda.
\end{abstract}

Key Words: Rice paddy area, Agroecosystem, Anuran, Conservation, Pelophylax porosa brevipoda

要旨 : 世界的な両生類の減少が注目されるようになってから約 20 年間, 世界各地で両生類の減少理由や生態に関する研究が行われ, 様々な情報が蓄積されてきた。減少の理由は生息する地域や種によって異なるが，主に，生息地である湿地の減少や分断化，環境污 染であると考えられている. 日本においてもその例外ではなく, 天然湿地や森林の開発などによる両生類の減少が進しでいる. 日本 の里山景観においては, 湿地性生物の生息地の代替地として水田が重要な役割を果たしてきた。 しかし, 農業の近代化や耕作放衰地 の増加に伴い水田環境が変化し, 日本固有の水田生態系を代表寸る生物が絶减危惧種に指定されるようになった. カエル類の多くは 環境污染に敏感であり, また生活史の中で水陸両域を必要とするため, 水田環境の変化を反映する環境指標種として期待されている. その中でも絶㓕危惧種 IB 類に指定されている日本固有種ナゴヤダルマガエルは水田環境に強く依存し，農業依存種の代表とされて いる. 本種の生息場所は水田地域に限られているため, 具体的な保全計画策定に向けて, 水田における本種の生態に関する研究が求 められている. 本種の減少理由は水田における水管理の変化, 围場整備による乾田化, 近緑種であるトノサマガエルとの交雑などが 指摘されている. 本種は一年を通して水田に留まり, 繁殖活動や幼生の生存率などは水田の水管理に強く影響されている. また, 水 辺からほとんど離れない性質を持つため, 成体の生息地利用は水田周辺の水辺環境（素掘りの水路や，ビオトープなど）の有無や湛

*連絡先 : risa.naito.fmdk@gmail.com

受付 : 2012 年 11 月 8 日/受理 : 2012 年 11 月 21 日 
水期間に影響されている. また，畦は水田地域における重要な陸域環境として利用されており，本種による微生息地利用の研究は今 後の畦管理について示唆を与えるものである. 本論文では, 両生類の置かれている状況, 水田環境とカエル類の関係, 農地における 生物の保全，ナゴヤダルマガエルの生活史や生態を整理し，カエルの水田における保全，特にナゴヤダルマガエルの保全に向けた提 案を行った.

キーワード : 水田地帯, 農業生態系, 両生類, 保全, 絶滅危惧種

\section{AMPHIBIANS IN CRISIS}

The world is experiencing a biodiversity crisis: rapid and accelerating loss of species and habitat (Mayers 1990; Raven 1990). Populations of amphibians are declining and disappearing even from protected areas worldwide at an increasing rate as compared to the pre-1980 decades (Blaustein and Wake 1990; Wyman 1990; Wake 1991; Stuart et al. 2004). The International Union for the Conservation of Nature (IUCN) Red List of Threatened Species lists $32 \%$ of described amphibians as threatened or extinct, a higher percentage than in mammals (21\%) and birds (12\%) (IUCN 2008).

Amphibians are considered "bioindicators" of environmental quality. Their decline has been considered an indication of stressed environments associated with decreased water quality and ecosystem biodiversity (Vitt et al. 1990; deMaynadier and Hunter 1995; Licht and Grant 1997). The complex life cycles, aquatic eggs, and permeable skin of many amphibians are thought to make them especially sensitive to environmental contaminants (Blaustein 1994). Additionally, amphibians play key roles in energy flow and nutrient cycling in a variety of ecological communities because they serve as both predator and prey (Fisher and Shaffer 1996; Crump 2010). Information concerning amphibian populations may therefore be important for understanding and managing ecological systems (Licht and Grant 1997).

Apparent reductions of amphibian populations have alarmed the scientific community and led to an intensification of research (Blaustein and Wake 1990; Pechmann and Wilbur 1994; Alford et al. 2001). This research has included discussions of possible world-wide or regional trends (Blaustein et al. 1994; Alford and Richards 1999; Houlahan et al. 2000; Touchon and Warkentin 2009), effects of diseases (Daszak et al. 2003), the fungal pathogen, Batrachochytrium dendrobatidis (Smith et al. 2006; Bielby et al. 2008), introduced predators (Kupferberg 1997), increased UV radiation (Licht and Grant 1997), acidification (Räsäsnen et al. 2002), chemical pollution (Sparling and Lowe 1996), intensive agriculture (Bonin et al. 1997; Lehtinen et al. 1999; Kolozsvary and Swihart 1999; Storfer 2003), herbicides (Hayes et al. 2003; Kiesecker 2002), global climate change (Collins and Storfer 2003) and habitat destruction (Delis et al. 1996). In many cases multifactorial studies are required to understand the causes of a decrease (Gardner 2001; Storfer 2003; Loman and Andersson 2006) because it can occur in any combination of life history stages for organisms with complex life cycles (Wilbur 1980). Identifying susceptible species in advance of their decline is particularly important in setting priorities as declines are hard to stop once initiated (Bielby et al. 2008).

\section{AMPHIBIANS IN JAPAN}

In Japan, 60 species and five subspecies of amphibians (three families, six genera and 22 species of Urodelans and five families, ten genera, 38 species and five subspecies of Anurans) have been recorded (Matsui 2005). This number is not large in international comparison, however $80.4 \%$ of these species are endemic, which is a comparatively high percentage (IUCN SSC Amphibian Red List Authority 2004; Matsui 2005).

Species structures in the Ryukyu Archipelago and on the main islands (Hokkaido, Honshu, Shikoku and Kyushu) are distinctive. Two urodelan species, 16 anuran species and one anuran subspecies are found in the Ryukyu Archipelago, and 20 urodelan species, 18 anuran species and four anuran subspecies are distributed on the main islands (Ota 2000).

Declines of amphibian populations have also been reported from Japan. 34\% of species are listed on the Japan Red List (Ministry of Environment 2006). Deforestation is considered the major threat for amphibian populations in the Ryukyu Archipelago (Ota 2000) whereas habitat loss and deterioration of inland water 
environments play the principal roles on the main islands (Hasegawa et al. 2000).

\section{WETLANDS AND RICE PADDIES}

Although wetlands maintain high levels of biodiversity and provide important ecological services (Zedler and Kercher 2005), they are one of the habitat types most threatened by human landscape modification (Keddy et al. 2009). In Japan, more than $61 \%$ of natural wetland has been lost in the last 100 years (Geospatial Information Authority of Japan 2000). In Monsoon Asia, natural wetlands have largely been converted into rice paddies. As rice paddies have seasonal exposure to flooding and drying, they are viewed as semi-natural (defined as habitats modified by human but still retaining many natural features) wetlands or temporal water pools managed by humans (Heckman 1979; Hidaka 1998; Ramsar Convention 2008). Rice paddies have played an important ecological role as substitute habitat for organisms that would have originally inhabited wetlands or floodplains (Moriyama 1997; Lawler 2001).

Almost all rice paddies in Japan are irrigated, thus they are connected to various habitats (such as grasslands, forests, and irrigation ponds) through irrigation systems. Organisms live within and freely move around rice paddies and their various surroundings (Moriyama 1997; Saijo 2001; Ohba and Goodwyn 2009). Over the more than 2,500-year history of rice cultivation in Japan (Yamazaki 1996), wetland organisms have adjusted their life cycles to the rice cultivation schedule, and species that have adjusted more successfully have flourished in the rice paddy ecosystem (Moriyama 1997). The long history of rice cultivation and the mosaic structure of rice paddy areas have created "Satoyama" landscape (a Japanese traditional socio-ecological production landscape) and enabled the support of rich indigenous ecosystems.

\section{CHANGES IN THE RICE PADDY ECOSYSTEM}

Since the 1950's, the modernization of agriculture has dramatically changed rice paddy areas and their ecosystem through land consolidation and improvement projects (Kiritani 2000). For example, irrigation and drainage water formerly flowed through the same shallow, earthen ditch, but now are routed through different channels. Deep, concrete drainage channels were constructed to increase the drainage of paddies, and U-shaped concrete irrigation channels or culverts were constructed for easier management (Fujioka and Lane 1997). The difference in water level between rice paddies and drainage channels has become so large that aquatic organisms can no longer move freely between them (Nakagawa 1978; Saitoh et al. 1998; Katano et al. 2003). In addition the yearly rice paddy management schedule, including the water regime, has also changed (Lane and Fujioka 1998), as have the agrochemicals and chemical fertilizers used in rice paddies. These changes and abandonment of farming have led to habitat loss, fragmentation and degradation, which has had negative impacts on many groups of organisms (Ministry of Agriculture, Forestry and Fisheries 2007; Natuhara 2012).

In light of these problems, rice paddies are now being reevaluated as not only fields for rice production, but also as important habitats for many organisms (Ministry of Agriculture, Forestry and Fisheries 2007). Kiritani (2010) reported 5,668 species in rice paddies and related areas in Japan. Rice paddies produce rice and simultaneously support a diverse group of organisms, but their complexity makes it difficult to evaluate them as habitats. The structure of a rice paddy varies depending on its location and condition, and paddies tend to be managed differently by different farmers. In addition, diverse organisms use paddies for different time periods, and the life histories of these organisms frequently are not well studied. To fully understand the rice paddy ecosystem and to evaluate the paddy as a unique ecosystem worth conserving for wildlife, we need to study the relationship between the environmental factors governing rice paddies, such as water management and surrounding land use, and the organisms living there.

\section{FROGS IN THE RICE PADDY ECOSYSTEM}

Among the organisms living in rice paddies, frog species are very common and representative (Osawa et al. 2003; Sato and Azuma 2003). There are two main reasons to regard them as important study taxa. First, frogs are good indicators of environmental quality (Ezaki and Tanaka 1998). As most frogs are sensitive to pollution (Boyer and 
Grue 1995) and need both aquatic and terrestrial habitats to complete their life cycles (Matsui 2005), frog population dynamics closely reflect changes in environments, such as increased agrochemical use or habitat fragmentation (Osawa and Katsuno 2003). Second, the rice paddy forms an important substitute habitat for anuran species (Maeda and Matsui 1999; Matsui 2005). On the main islands of Japan (Hokkaido, Honshu, Shikoku, and Kyushu), 15 of 19 anuran species and subspecies are found in rice paddies (Ministry of Agriculture, Forestry and Fisheries 2010), and these populations are decreasing due to rapid change in the rice paddy environment (Moriyama 1997). Evaluating the rice paddy as a frog habitat is an urgent task for frog conservation (Matsui 2005).

More than half of Japan's frog species belong to the Ranidae family. Six Ranidae genera (Pelophylax, Glandirana, Babina, Odorrana, Rana, Lithobates) have been recorded in Japan (Frost et al. 2006). The one recorded species of Lithobates (the American bull frog, $L$. catesbeianus) is non-native. Babina and Odorrana species were distributed in the Ryukyu Archipelago, the rest on the main islands. Some Rana species breed in lotic environments (pond-breeding frogs) and inhabit forest in mountainous areas. The remaining species of Rana as well as of Pelophylax and Glandirana breed in lotic lowland environments and stay territorial during the non-breeding season. Pelophylax and Glandirana species are of southern origin and breed during the rice cultivation season in spring or summer. A subset of Rana species also breeds in rice paddies. However, their relationship with the rice cultivation schedule is not as extensive as it is for Pelophylax and Glandirana species due to their northern origin the fact that they breed in winter, preceding the rice cultivation season. One species of Glandirana was recorded (G. rugosa). It is characteristic of the species that some of the larvae overwinter and metamorphose in the following spring, whereas the larvae of Pelophylax species metamorphose before winter. In the genus Pelophylax, two species and one subspecies were recorded $(P$. nigromaculatus, P. porosa porosa and P. p. brevipoda). Their natural habitats are lowland areas and hilly inland wetlands, most of which have been converted to rice paddies. Rice paddy areas have acted as important substitute habitat for these species. P. p. porosa and P. p. brevipoda are mainly found in lowland areas and compared to P. nigromaculatus have a stronger tendency to stay close to water edges during the non-breeding season. P. p. porosa and P. p. brevipoda are thought to constitute suitable indicator and also umbrella species for rice paddy ecosystems (Ito 1999).

\section{FROG CONSERVATION IN RICE PADDY AREA}

Conservation of frog species in agroecosystems requires the investigation of the role of agroecosystems in providing habitat (Ricketts et al. 2001) and an understanding of factors influencing frog assemblages (Peltzer et al. 2006). Furthermore, habitat restoration for pond-breeding frogs can be successful if it is biologically based, implemented at the landscape scale, and taking species-specific habitat requirements into account (Denton et al. 1997; Semlitsch 2002; Rannap et al. 2009). A starting point is the investigation of the influence of rice paddy environmental factors at individual paddy and landscape scales on habitat use of each frog species and larvae population (Berven 1990). For example, on the macro scale, the effects of landscape structure (Osawa and Katsuno 2003; Van Buskirk 2005), paddy drainage (Hasegawa et al. 2000), irrigation and drainage channel design (Azuma and Takeuchi 1999), and land consolidation projects (Fujioka and Lane 1997; Ezaki and Tanaka 1998; Togane et al. 2005) have been studied. On the micro scale, the effects of the vegetation type on paddy levees (Sato and Azuma 2003) and the cultivated rice type (Murakami and Osawa 2008) have been examined. However, only a few studies have investigated the effects of environmental factors of individual rice paddies on habitat use by frog species throughout the whole year (e.g. Togane et al. 2005; Murakami and Osawa 2008). To evaluate rice paddies as frog habitats, information pertaining to the interior regions of rice paddies as well as broader aspects of the environment are required, and also on the time scale, the information not only daily but also year-round water management and availability is required (Naito et al. 2012b). Furthermore, at site level, interspecific and intra-specific competitions among frogs are needed to be examined.

As the influence of habitat fragmentation on population persistence needs to be considered, effective 
management must account for the behavioral characteristics of anuran species as well as life history requirements (Peltzer et al. 2006). The relative effects by habitat fragmentation and degradation vary depending on species dispersal ability (Gibbs 1998; Cushman 2006; Tsuji et al. 2011) and seasonal movement patterns (Naito et al. 2012a). For pond-breeding frogs and salamanders that have relatively limited mobility and require different habitats at different life stages, the persistence of a population depends on maintaining dispersal and migration among the necessary habitats (Sinsch 1990; Semlitsch 2000; Marsh and Trenham 2001). Although the construction of deep concrete-lined channels is widely considered to negatively influence the abundance of some frog species in rice paddy areas (Azuma and Takeuchi 1999), the specific influences of deep channels on frog dispersal or migration in these habitats remain relatively unexamined. Since habitat fragmentation leads to reduced genetic diversity even before a population declines (Forman and Alexander 1998; Tallman et al. 2004), it is an urgent task to examine the impacts of roads and deep concrete-lined channels on the frogs in rice paddy area. Information of the species' behavioral characteristics at the landscape level is also vital to examine the interaction among local populations. If isolated populations are connected by channels or other corridors, the risk of local extinctions can be reduced and genetic diversity improved as well (Blaustein et al. 1994; Tallman et al. 2004).

Anuran species generally require both terrestrial and aquatic habitats to complete their life cycle, so both types need to be taken into account (Stumpel and van der Voet 1998; Porej and Hetherington 2005). Previous studies have shown that an increase of the coverage and diversity of vegetation attracts more anuran species and promotes breeding and survival (Rothermel and Semlitsch 2002; Mazerolle and Desrochers 2005; Peltzer et al. 2006). Levees surrounding rice paddies (also used as walking paths) are usually covered with semi-natural grassland (Umematsu et al. 2010) and provide crucial terrestrial habitat for rice paddy anuran species (Osawa et al. 2006; Osawa and Katsuno 2007). The importance of terrestrial habitat in rice paddies has however tended to be overlooked (Osawa et al. 2005). In some urban areas, levees are converted to concrete blocks to reduce maintenance costs for farmers and widen paddy areas
(Tsuji et al. 2011). Previous studies have shown that the structure of rice paddy areas, such as whether a channel is earthen or lined with concrete was the most influential factor regulating frog abundance at levees (Osawa et al. 2006). Although the daily activities of frogs are influenced by microhabitat (Morey 1990; Zug 1993; Smith et al. 2003), only a few studies have examined fine-scale habitat use among species (Sato and Azuma 2003; Osawa and Katsuno 2005). Furthermore, although the size (snout-vent length, SVL) distribution of frogs varies among microhabitats (Sato and Azuma 2003; Osawa et al. 2005), the microhabitat uses of different size groups or sexes have not been well analyzed in relation to habitat ecological roles, such as the provision of basking sites or shelter (Hayashi 2007). Microhabitat use in levees needs to be investigated to produce insights into the ecological role of levees as terrestrial habitat and for their proper management.

There used to be both semi-permanent and seasonal wetland environments in rice paddy area; water pools existed throughout the year in earthen ditches or irrigation ponds, and rice paddies are flooded seasonally. Previous studies have shown that protecting wetlands with varying hydroperiods helps maintain amphibian habitats where amphibians breed in both seasonal and semi-permanent wetlands (Karraker and Gibbs 2009). It is important to develop an understanding of the relative contributions of wetlands of different hydroperiods to local population persistence (Wellborn et al. 1996; Knutson et al. 2004). In modernized rice paddy areas, wetland environments are only available to organisms only seasonally because rice paddies are flooded only during the cultivation season.

For the rest of this paper, I reviewed especially about the Nagoya Daruma pond frog (Anura: Ranidae, Pelophylax porosa brevipoda Ito, 1941) as prioritized frogs for conservation in rice paddy areas due to its status as an endangered species and the close relationship to the rice paddy environment and the rice cultivation schedule. $P$. p. brevipoda is endemic to Japan and the only frog with a distribution on the main island, Honshu, that is listed in the Endangered (IB) category of the Japan Red List (Ministry of Environment 2006). Most of its natural habitat has been lost, and currently no population in natural habitat is known - it is exclusively distributed in rice paddies (Okochi et al. 1997). The frog now strongly 
depends on the rice paddy environment, and the population would go locally extinct if rice cultivation was stopped (Kameyama et al. 2006). Therefore, it is an urgent task to study the frogs closely and find ways to conserve them in rice paddies.

\section{Nagoya Daruma pond frog (Pelophylax porosa brevipoda)}

\section{Synonyms}

The Nagoya Daruma pond frog was first described by Ito (1941) as a subspecies of the Black-spotted pond frog (Pelophylax nigromaculatus, Hallowell, 1861) and named Rana brevipoda (Serizawa and Serizawa 1982). Based on the morphological variations of the Black-spotted pond frog across its geological distribution, Moriya (1954, 1956) later divided $P$. nigromaculatus into five races: Black-spotted pond frog, Okayama Daruma, Nagoya Daruma, Tokyo intermediate, and Niigata intermediate. Kawamura (1962) conducted hybridization experiments and divided these races into two species and one subspecies: Black-spotted pond frog R. nigromaculata (Black-spotted pond frog race), Daruma pond frog Rana brevipoda brevipoda Ito (Okayama and Nagoya Daruma races) and Tokyo Daruma pond frog Rana brevipoda porosa Cope (Tokyo and Niigata intermediate races). Because of the priority of Cope's name, Daruma pond frogs were renamed Rana porosa brevipoda Ito and Rana porosa porosa Cope (Sumida and Ishihara 1997). To avoid confusion between the Daruma pond frog and the Tokyo Daruma pond frog, the former has been renamed as
Nagoya Daruma pond frog as of the 2006 edition of the Japan Red List.

Phylogenetic relationships among Raninae were investigated and new genera suggested (Frost et al. 2006; Che et al. 2007). Rana nigromaculata, Rana porosa porosa and Rana porosa brevipoda were regrouped into Pelophylax. Arguments concerning the reasonability of the newly suggested phylogenetic system do however persist (Matsui 2006; Kuramoto 2006).

\section{Distribution}

P. p. brevipoda is distributed from Aichi to Hiroshima Prefecture (Pref.) as well as in a part of Shikoku, and there are isolated populations in Nagano Pref. (Fig. 1). The species is subdivided into two races: the Okayama race is found in western Japan (Chugoku area) and the Nagoya race in central Japan (Tokai to Kinki area). They have similar morphology but different call phonetics (Maeda and Matsui 1999).

The nominotypical subspecies $P$. porosa porosa is found in Hokkaido (introduced by humans) and from Miyagi Pref. to Nagano Pref. (Fig. 1). P. p. porosa and P. p. brevipoda are two very distinct parapatric subspecies that are known to have different ecological and morphological characteristics (Kaneko and Matsui 2004; Maeda and Matsui 1999).

P. nigromaculatus is phylogenetically very close and widely distributed from Hokkaido (introduced by humans), to Honshu with the exception of the Kanto and

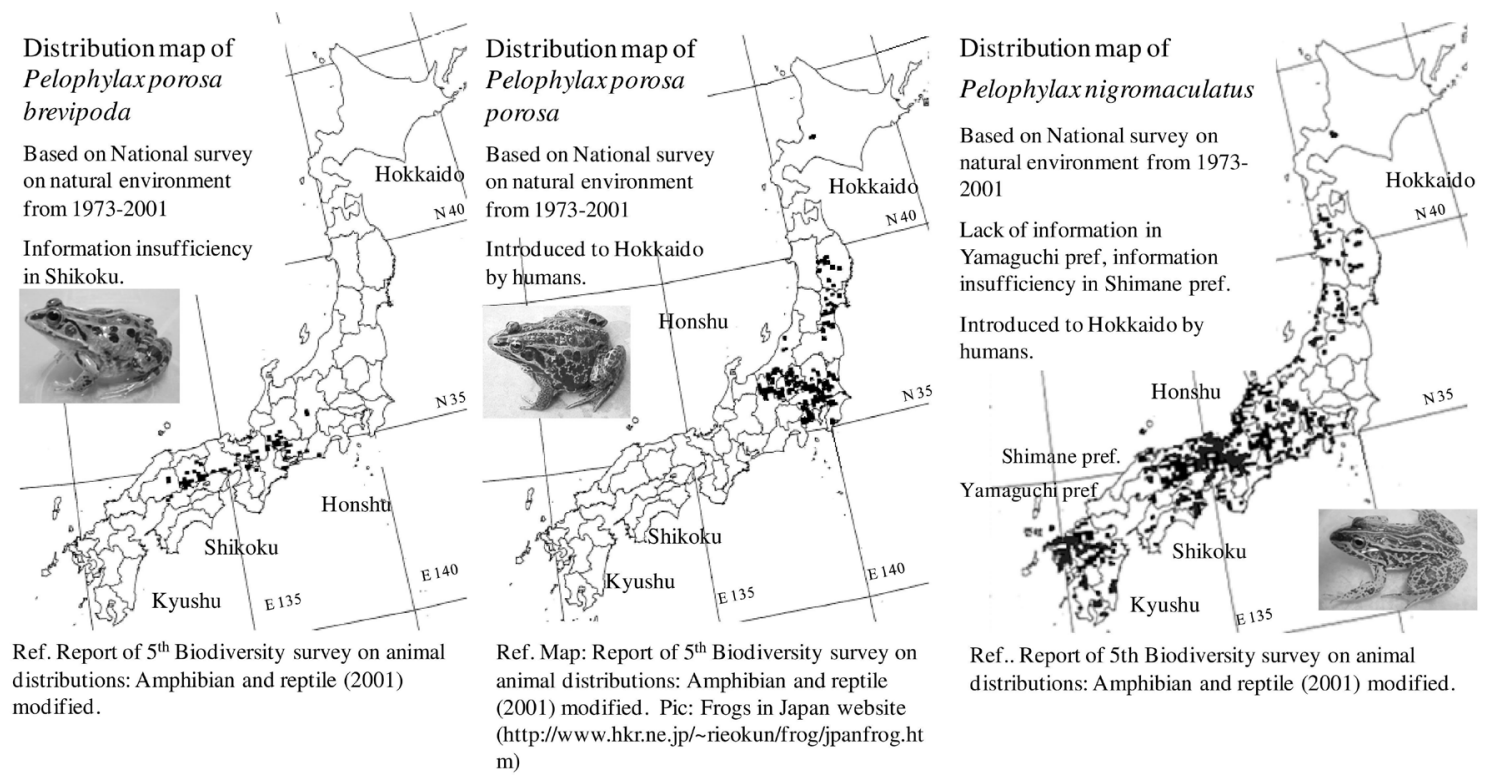

Fig. 1 The distribution maps of Pelophylax porosa brevipoda, Pelophylax porosa porosa and Pelophylax nigromaculata. 
Sendai plains, Shikoku and Kyushu in Japan (Fig. 1). The species is also found outside of Japan in China, Korea and the Amur basin of Russia. P. nigromaculatus and P. $p$. porosa are allopatric except for the Shinano River area in Nagano Pref. and a part of Niigata Pref., but $P$. nigromaculatus and $P . \quad$ p. brevipoda are sympatric throughout their range.

\section{Speciations}

The speciation process among P. nigromaculatus, P. $p$. porosa and P. p. brevipoda has received much attention. Moriya (1954) hypothesized that the Tokyo Daruma pond frogs had evolved from hybridizations between the Blackspotted pond frog and the Daruma pond frog. However, Serizawa and Serizawa (1982) studied morphological variation in the Daruma pond frog in the western Tokai district and questioned the hypothesis, suggesting an influence of natural selection and expansion of distribution area on speciation. The hybridization hypothesis has now been rejected based on DNA analysis (Sumida et al. 1998) which has led to further discussion of speciation details.

Two migration events and two geographical isolation events in glacial periods lead to the speciations of three sister groups, P. nigromaculatus, P. porosus and the Eastern golden frog (Pelophylax plancyi Lataste, 1880), from a common ancestor population in central China (Hikita 1989; Nishioka et al. 1992; Sumida et al. 2000; Zhang et al. 2008). It is estimated that a glacial period split the ancestor population into northern and southern populations, and that $P$. plancyi is the descendant of the southern and $P$. nigromaculatus of the northern population (Hikita 1989). The two species are assumed to have diverged 2.93 million years ago (MYA) (Liu et al. 2010). Currently, P. plancyi is a common and widespread species in eastern Asia (Liu et al. 2010). In a later glacial period the disconnection between Japan and the Korea peninsula resulted in a part of the northern population being isolated in Japan, the descendant being P. porosus (Hikita 1989). $P$. nigromaculatus and $P$. porosus are assumed to have diverged 3-5 MYA (Sumida et al. 1998). Because $P$. porosus migrated to Japan before the eruption of Mt. Fuji and the formation of high mountains around the Kanto and Sendai plains, the species was able to enter the Kanto plain. P. p. porosa and P. p. brevipoda (including its two races) are estimated to have diverged 1-2 MYA due to geographic barriers such as the high mountains in the IzuHakone area (Sumida et al. 1998). During the last glacial period (0.01-0.07 MYA), P. nigromaculatus emigrated from the continent to Japan and expanded its distribution, but was prevented from entering the Kanto plain by geographic barriers. The period since then has not been sufficient for speciation of the Japanese population (Moriyama 1997).

\section{Life history}

P. p. brevipoda is highly riparian and rarely leaves the water's edge (Sawahata 2002; Doi et al. 2005), remaining in rice paddy areas during both breeding and non-breeding seasons (Maeda and Matsui 1999). Breeding takes place from April to July, followed by metamorphosis. The male frog defends a territory (average size $1.18 \mathrm{~m}^{2}$ ) while attracting females with its mating call. After pairing with a female the territory is discarded and both animals move to an oviposition site (Inoue 1979). The frog hibernates in a moist underground burrow, although details about hibernation sites are lacking (Doi et al. 2001). Some large females deposit egg clutches twice in a breeding season, which lasts two months or longer (Serizawa 1983). The second clutch (500-1300 eggs) is smaller than the first one (1500-3000 eggs) (Serizawa 1983; Numazawa and Okochi 2006). If the first egg clutch deposition has been delayed, the second clutch is not deposited even if they are already developed (Serizawa 1985). Eggs hatch $\sim 20$ days after deposition and larvae metamorphose after another $\sim 2$ months (Iwasawa and Morita 1980). Males become sexually mature in the year of their metamorphosis, females in that year or by the time of the following year's breeding season. An exception is the Ina Basin, Nagano, were because of high elevation and cooler climate it takes longer for the larvae to metamorphose and for females to become sexually mature (Shimoyama 1986 2000). Females here become sexually mature in the following year and start breeding a year after that (Shimoyama 2000). The SVLs of mature males are between 35-62 mm, while those of females are between $37-73 \mathrm{~mm}$, females being larger than males (Maeda and Matsui 1999). Based on skeletochronology, the survival rate in the wild is very low during the $1^{\text {st }}$ year but gradually increases after that; average longevity in the wild is estimated at four years (Khonsue et al. 2002). In captivity, maximum longevity 
was estimated at 7-8 years (Numazawa and Okochi 2006).

Prey availability around frog habitats regulates availability of the species' food items. It is considered as a generalist predator and feeds on a wide variety of terrestrial insects (mainly Formicidae, Coleoptera, Diptera, Hemiptera and Orthoptera) and aquatic insects (mainly larval water beetles, waterstriders, nymphal dragonflies, pond snails and leeches), spiders and small frogs (Hirai and Matsui 2000, 2001). Common predators are aquatic insects such as water scorpions, the American bull frog, snakes and herons. The species has short hind limbs and lower mobility compared to P. nigromaculatus (Doi 2002). Their feet lack suckers, and thus they have difficulty climbing concrete-lined walls higher than $38 \mathrm{~cm}$ and almost no ability to climb higher than $58 \mathrm{~cm}$ (Doi 2001).

Regardless of intensive research on reproductive traits, breeding habitats, genetics and morphology, ecological information about P. p. brevipoda is still lacking (Hirai and Matsui 2001; Khonsue et al. 2002). Due to this lack of information, the question why only this species among rice paddy pond-breeding frogs is decreasing rapidly remains unanswered (Doi. 2001).

\section{Status in Red Lists}

When the first Japan Red List was compiled in 1991, P. p . brevipoda was listed as Rare (R). The species' rank was increased to Vulnerable (VU) during the list's revision in 1997 and increased again to Endangered (IB) during the 2006 revision, because of rapid declines. The species is listed on 15 prefecture-level Red Lists.

The nominotypical subspecies $P$. p. porosa is listed as Nearly Threatened on the 2006 Japan Red List and on eight prefecture-level Red Lists. The decline of $P$. nigromaculatus reported from different parts of Japan (Yoshida et al. 2007) has led to it being listed on 22 prefecture-level Red Lists.

\section{Threats}

Even though $P . p$. brevipoda has declined at an alarming rate, no populations are found in any legally protected reserves such as national parks or nature reserves. The main threats for the species are loss of and environmental changes in rice paddies (Khonsue et al. 2002; Suzuki et al. 2002), especially changes in yearly water management and improvements of drainage by agricultural modernization (Ito 1997). Gaps between the periods during which the rice paddy is being flooded and the periods during which the species requires wetland

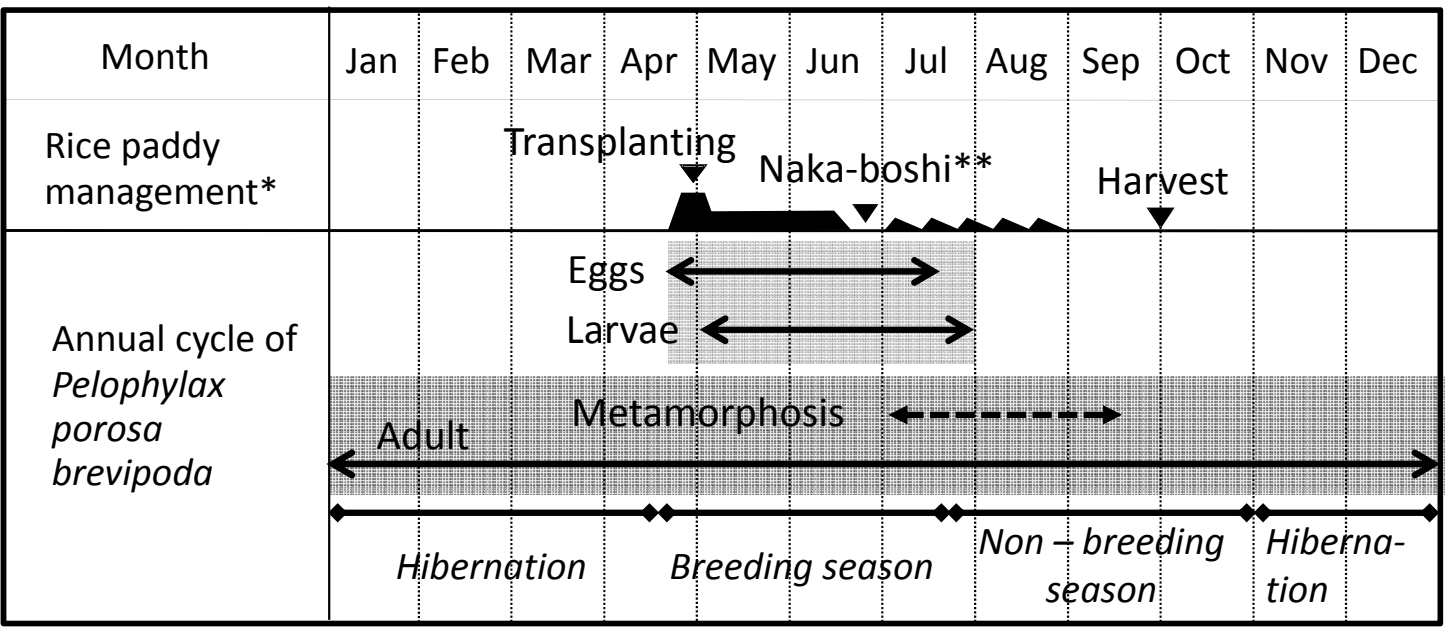

Legends:

Annual water management. Height indicates water level in the rice paddy.

The period of time when the frog needs water pools.

De period of time when the frog needs wet environment.

Note: * An example of rice paddy management in Shiga prefecture.

** Naka-boshi is one of water managements in rice paddies. Rice paddies are drained for naka-boshi, and the soil was dried to release harmful gases from the soil and to supply oxygen to the rice roots for a week or two in June or July

Fig. 2 The relationship between rice paddy management and annual cycle of Pelophylax porosa brevipoda. 
environments have been increasing (Fig. 2).

The gap results in a loss of egg deposition chances. As mentioned above, some of large females deposit twice in a breeding season, but if the first deposition is delayed, the second clutch of eggs is not deposited (Serizawa 1985). Since P. p. brevipoda prefers large water surfaces as breeding sites, the species does not deposit egg clutches until rice paddies are flooded. In some areas, rice paddies are no longer flooded early enough to allow two egg deposits, directly decreasing new population recruitment. In contrast, $P$. nigromaculatus deposits egg clutches once during breeding season in narrow channels as well as rice paddies and thus the gap was not considered as a threat (Serizawa 1983).

As P. p. brevipoda has a strong dependency on wetland environment throughout the year, the loss of semi-permanent wetland environments through drainage improvement is considered one of the main reasons for population decline. Pools in earthen ditches or irrigation ponds have been used to compensate for the absence of such environments while rice paddies are not flooded, but most of them have been lost. Attempts have been made to create semi-permanent pools for population recovery, but basic information related to demographic characteristics and population dynamics in such created environments is insufficient. Such information is necessary to understand the roles of different hydroperiod environments for the species' population persistence.

At the genetic level, hybridization between $P$. nigromaculatus (Nishioka et al. 1992; Sumida and Ishihara 1997; Suzuki et al. 2002; Komaki et al. 2012) has been reported. Hybrid males were fertile (Moriya 1960) but females were not; they regained reproductive capability after generations of back-crossing (Moriya 1965). The breeding season of $P$. nigromaculatus was considered to be earlier than that of P.p. brevipoda (Moriya 1951), and the reason for hybridization occurrences was assumed to be the collapse of seasonal reproductive isolation between the two species (Moriya 1960). However, Serizawa (1983) studied female reproductive cycles, finding no distinctive seasonal isolation but differences in favorable breeding habitats between the species. As mentioned above, P. p. brevipoda needs a larger water surface than $P$. nigromaculatus to deposit its eggs, thus if both species occur sympatrically and large water surfaces exist, natural hybridization can occur (Serizawa 1983). Another reason for hybridization is that the species' mating calls are very similar, and male $P$. nigromaculatus do not distinguish well between them and tend to join the P. p. brevipoda chorus. Therefore, most interspecific amplexus consisted of male $P$. nigromaculatus and female P. p. brevipoda (Shimoyama 2000). This accelerates the introgression of $P$. nigromaculatus into $P$. $p$. brevipoda and the loss of pure P. p. brevipoda genetic information (Sumida and Ishihara 1997). Although studies have been conducted to examine the reproductive isolation mechanism between these species and reveal the causes of hybridization occurrences, the mechanisms are not yet fully explained (Shimoyama 1996, 2000, 2005).

\section{PERSPECTIVES FOR $P . p$. brevipoda CONSERVATION}

In this section, I summarized the habitat provided by rice paddies, suggested key factors for evaluating rice paddies as habitat and discussed implications for P. p. brevipoda conservation.

1. Habitats provided by rice paddies and key factors for their evaluation

(1) Aquatic habitat

Rice paddies are considered seasonal pools. They play an important role as breeding habitat to provide new recruits for the local population. The number of egg clutches is regulated by the timing of paddy irrigation in spring. If the paddy is flooded early enough, large females can deposit egg clutches twice during one breeding season (Serizawa 1985). The survival of larvae is strongly influenced by water management for rice cultivation, especially nakaboshi (to dry out rice paddy for 1-2 weeks in June or July). The water management schedule is a crucial abiotic factor for aquatic habitat evaluation. For further study, the abiotic factor, the influence of agrochemicals, and the biotic key factor, predation pressure from non-native predators, especially on larvae and juveniles will need to be examined.

Connectivity between rice paddies and drainage channels is a key factor for evaluating both breeding and non-breeding habitats (Naito et al. 2012b). The causes of the direct relationship between connectivity and habitat use could not be determined but are assumed to be related 
to food resource availability in rice paddies.

\section{(2) Terrestrial habitat}

Levees provided essential terrestrial habitat for juveniles and adults and performed ecological roles by providing sites for basking, foraging, shelter from predators (Osawa et al. 2005; Sato and Azuma 2003; Crump 2010) and overwintering. Microhabitat use in levees varied among different life stages, sexes and group sizes (Naito et al., unpublished data). Water depth and vegetation cover height were key factors for terrestrial habitat evaluation. In general, the abundance of frogs was high in levees with sheltering vegetation. The influence of water depth varied among different groups.

\section{(3) Surroundings}

The species rarely leaves the waterside (Sawahata 2002; Doi et al. 2005); however juveniles in summer and adults in the fall did leave rice paddies (Naito et al. 2012a). The reasons of the leaves were assumed to be the combination of the frog's life history traits and rice paddy management. The structure of channels and the length and depth of channels and roadside ditches were key factors for evaluating the degree of habitat fragmentation. Success rates for dispersal or migration were influenced the degree of habitat fragmentation.

Semi-permanent water pools acted as refuges for frogs during the time that rice paddies were dry. Especially in winter such environments provided suitable hibernation sites. In modernized rice paddies where drainage performance is high, the availability of the semipermanent water pools is a key factor for habitat evaluation for adult populations (Naito et al., unpublished data).

At the landscape scale, urbanization decreased adult habitat use during the breeding season. Because frogs remain in rice paddies throughout the year, the degree of urbanization around paddies rather than the availability of non-breeding sites requires attention, although the latter is commonly considered a key factor for frog habitat evaluation.

\section{Implications for conservation}

Because currently no $P$. p. brevipoda population is known in natural habitat, we need to find a suitable way to conserve the species in rice paddies. The following are some suggestions for the implementation of conservation plans and management approaches.

(1) Prioritize rice paddies in less urbanized areas as conservation sites.

(2) Connect rice paddies and drainage channels by e.g. setting a fish ladder. By ensuring connectivity, the value of rice paddies as aquatic habitat is increased during both the breeding and non-breeding season (Naito et al. 2012b).

(3) Flood rice paddies early enough for large females to deposit two egg clutches (Serizawa 1983; Serizawa 1985) and eliminate non-native aquatic predators, such as the American bull frog or the Red swamp crawfish, to increase the value of rice paddies as breeding habitat.

(4) Give consideration to larvae survival by adjusting water management, delaying naka-boshi to August, or digging deep ditches as refuge pools inside rice paddies.

(5) Adopt countermeasures to fragmentation to increase the success rates of dispersal and immigration. Putting lids over deep ditches or channels is considered more efficient than fitting nets or slope into such features (Mizutani et al. 2005; Watabe et al. 2012).

(6) Conserve heterogeneous vegetation cover at levees and water depth in paddies next to levees to support different life stages, sexes and sizes.

(7) Create biotopes and manage them as semi-permanent water pools to aid population persistence in the area. Biotopes can support larger frogs, especially females with high fecundity, by providing suitable hibernation sites and refuge during periods when the rice paddy is not flooded (Naito et al., unpublished data). Plants that grow higher and faster than rice are recommended as vegetation inside pools to protect the adults from predators such as herons. Connectivity between rice paddy and biotope needs to be ensured.

To develop effective management and recovery strategies, it is essential to study basic life history and population dynamics (Kellner and Green 1995; Goldingay and Newell 2005). At the same time, agricultural landscapes have a multifunctional nature from an 
ecological as well as from a local economy and land use perspective (Milne and Bennett 2007). There are successful examples of promoting biodiversity-conscious rice farming by collaborations among farmers, consumers and governments (Natuhara 2012). It is therefore important for long-term conservation success to continue population monitoring, seek discussions with stakeholders and apply adoptive management practices.

\section{Acknow ledgements}

I am grateful to Prof. S. Shibata, Prof M. Kato, Prof. K Fukamachi, Prof. Y. Morimoto (Kyoto Gakuen University) and Prof. Y. Natuhara (Nagoya University) for their invaluable support during my research. I thank my fellows at the laboratory for encouragements for my research.

\section{References}

Alford, R. A., Dixon, P. M., Pechmann, J. H. K. 2001. Global amphibian population declines. Nature 412: 499-500.

Alford, R. A., Richards, S. J. 1999. Global amphibian declines: a problem in applied ecology. Annu Rev Ecol Syst 30: 133-165.

Azuma, A., Takeuchi, K. 1999. Relationships between population density of frogs and environmental conditions in Yatsu-habitat. J Jpn Inst Landsc Archit 62: 573-576. (in Japanese)

Berven, K. A. 1990. Factors affecting population fluctuations in larval and adult stages of the wood frog (Rana sylvatica). Ecology 71: 1599-1608.

Bielby, J., Cooper, N., Cunningham, A. A., Garmer, T. W. J., Purvis, A. 2008. Prediction susceptibility to future declines in the world's frogs. Conserv Lett 1: 82-90.

Blaustein, A. R. 1994. Chicken Little or Nero's fiddle? A perspective on declining amphibian populations. Herpetologica 50: 85-97.

Blaustein, A. R., Wake, D. B. 1990. Declining amphibian populations: a global phenomenon? Trends Ecol Evol 5: 203-204.

Blaustein, A. R., Wake, D. B., Sousa, W. P. 1994. Amphibian declines - judging stability, persistence, and susceptibility of populations to local and global extinction. Conserv Biol. 8: 60-71.
Bonin, J., DesGrange, J., Rodrigued, M. 1997. Anuran Species richness in agricultural landscapes of Quebec: foreseeing long-term results of road call surveys. Herpetal Cosero 1: 141-149.

Boyer, R., Grue, C. E. 1995. The need for water quality criteria for frogs. Environ Health Persp 103: 352-357.

Che, J., Pang, J., Zhao, H., Wu, G., Zhao, E., Zhang, Y. 2007. Phylogeny of Raninae (Anura: Ranidae) inferred from mitochondrial and nuclear sequences. Mol Phylogenet Evol 43: 1-13.

Collins, J. P., Storfer, A. 2003. Global amphibian declines: sorting the hypotheses. Diversity Distrib 9: 89-98.

Crump, M. L. 2010. Amphibian diversity and life history. Amphibian ecology and conservation (Dodd, Jr. C. K. eds.), 1-20. Oxford University Press, New York

Cushman, S. A. 2006. Effects of habitat loss and fragmentation on amphibians: A review and prospectus. Biol Conserv 128: 133-149.

Daszak, P., Cunningham, A. A., Hyatt, A. D. 2003. Infectious disease and amphibian population declines. Diversity Distrib 9: 141-150.

Delis, P. R., Mushinsky, H. R., McCoy, E. D. 1996. Decline of some west-central Florida anuran populations in response to habitat degradation. Biodiv Conserv 5: 1579-1595.

deMaynadier, P. G., Hunter, Jr. M. L. 1995. The relationship between forest management and amphibian ecology: a review of the North American literature. Environ Rev 3: 230-261.

Denton, J. S., Hitchings, S. P., Beebee, T. J. C., Gent, A. 1997. A recovery program for the natterjack toad (Bufo calamita) in Britain. Conserv Biol 11: 1329-1338.

Doi, T. 2001. Climbing ability of Daruma pond frog, Rana porosa brevipoda. Amphibi Hist 6: 25-27. (in Japanese)

Doi, T. 2002. How much is the difference in jumping ability between black-spotted pond frog, Rana nigromaculata and Daruma pond frog, Rana porosa brevipoda? Amphibi Hist 8: 12-16. (in Japanese)

Doi, T., Niwa, N., Kanemitsu, Y. 2001. The Daruma pond frog in Kobe city. Amphibi Hist 7: 27-32. (in Japanese)

Doi, T., Niwa, N., Tanaka, K., Harada, Y. 2005. Trial of estimating the population size of Daruma pond frog, Rana porosa brevipoda Ito, 1941, by mark-recapture method in rice field. J Nanki Biol 47: 89-92. (in Japanese) 
Ezaki, Y., Tanaka, T. 1998. Conservation of riparian area. 232pp. Asakura Publishing Co., Ltd., Tokyo (in Japanese)

Fisher, R. N., Shaffer, H. B. 1996. The decline of amphibians in California's Great Central Valley: historical patterns and anthropogenic causes. Conserv Biol 10: 414-425.

Forman, R. T. T., Alexander, L. E. 1998. Roads and their major ecological effects. Annu Rev Ecol Svst 29: 207-231.

Frost, D. R., Grant, T., Faivovich, J., Bain, R. H., Haas, A., Haddad, C. F. B., de Sá, R. O., Channing, A., Wilkinson, M., Donnellan, S. C., Raxworthy, C. J., Campbell, J. A., Blotto, B. L., Moler, P., Drewes, R. C., Nussbaum, R. A., Lynch, J. D., Green, D. M., Wheeler., W. C. 2006. The amphibian tree of life. Bull Am Mus Nat Hist 297: $1-370$.

Fujioka, M., Lane, S. J. 1997. The impact of changing irrigation practices in rice fields on frog populations of the Kanto Plain, Central Japan. Ecol Res 12: 101-108.

Gardner, T. 2001. Declining amphibian populations: a global phenomenon in conservation biology. Anim Biodiv Conserv 24: 25-44.

Gibbs, J. P. 1998. Amphibian movements in response to forest edges, roads, and streambeds in Southern New England. J Wildlife Manage 62: 584-589.

Geospatial Information Authority of Japan. 2000. Trends of wetland area in Japan (Research report) (http:// www1.gsi.go.jp/geowww/lake/shicchimenseki2.html), retrieved on 19 April, 2012. (in Japanese)

Goldingay, R. L., Newell, D. A. 2005. Population estimation of the Green and golden bell frog Litoria aurea at Port Kembla. Aust Zool 33: 210-216.

Hasegawa, M., Kusano, T., Fukuyama, K. 2000. How Have Declining Amphibian Populations Been Perceived by National, Academic and Regional Communities in Japan. J Nat Hist Museum Inst, Chiba Sp Ed 3: 1-7. (in Japanese)

Hayashi, T. 2007. Ecology of amphibian breeding at rice paddy. An introduction to paddy field eco-engineering for sustaining and restoring biodiversity in rural areas (Mizutani S eds.), 57-64. Rural Culture Association Japan, Tokyo (In Japanese)

Hayes, T., Haston, K., Tsui, M., Hoang, A., Haeffele, C., Vonk, A. 2003. Atrazine-induced Hermaphroditism at 0.1 ppb in American Leopard Frogs (Rana pipiens): Laboratory and field evidence. Environ Health Persp 11: 568-575.

Heckman, C. W. 1979. Rice field ecology in northeastern Thailand (Monographiae Biologicae v.34). 228pp. W Junk, Boston.

Hidaka, K. 1998. Biodiversity conservation and environmentally regenerated farming system in rice paddy fields. Jpn J Ecol 48: 167-178. (in Japanese)

Hikita, T. 1989. Amphibian and reptiles in Japan. Event description of 16th special exhibition 'All snakes and frogs together' (Osaka Museum of Natural History eds.), 3-13. Osaka Museum of Natural History, Osaka. (in Japanese)

Hirai, T., Matsui, M. 2000. Feeding habits of the Japanese tree frogs, Hyla japonica in the reproductive season. Zool Sci 17: 977-982.

Hirai, T., Matsui, M. 2001. Food habits of an endangered Japanese frog, Rana porosa brevipoda. Ecol Res 16: 737-743.

Houlahan, J. E., Findlay, C. S., Schmidt, B. R., Meyer, A. H., Kuzmin, S. L. 2000. Quantitative evidence for global amphibian population declines. Nature 404: $752-755$.

Inoue, T. 1979. On the territorial behavior of a Japanese pond frog, Rana brevipoda. Jap J Ecol 29: 149-161.

Ito, K. 1997. Field report of inhabiting situation of Daruma pond frog Okayama race and its conservation (I). B EPISJ 33: 165-178. (in Japanese)

Ito, K. 1999. Field report of inhabiting situation of Daruma pond frog Okayama race and its conservation (III). B EPISJ 35: 233-252. (in Japanese)

IUCN. 2008. The IUCN Red List of Threatened Species. IUCN, Gland (http://www.iucn.org/themes/ssc/redlist. html), retrieved on June 7, 2012

IUCN SSC Amphibian Red List Authority. 2004. Global Amphibian Assessment (www.globalamphibians.org), retrieved on Dec 2, 2011.

Iwasawa, H., Morita, Y. 1980. Normal stages of development in the frog, Rana brevipoda porosa (Cope). Zool Mag 89: 65-75. (in Japanese)

Kameyama, T., Morita, T., Okada, S., Naito, J., Utsunomiya, T. 2006. Crisis and reintroduction of the Okayama race of the Daruma pond frog, Rana porosa brevipoda. Jap J Conserv Ecol 11: 158-166. (in 
Japanese)

Kaneko, Y., Matsui, M. 2004. Pelophylax porosus. In: IUCN 2011. IUCN Red List of Threatened Species. Version 2011.2. (www.iucnredlist.org), retrieved on 19 June, 2012.

Karraker, N. E., Gibbs, J. P. 2009. Amphibian production in forested landscapes in relation to wetland hydroperiod: A case study of vernal pools and beaver ponds. Biol Conserv 142: 2293-2303.

Katano, O., Hosoya, K., Igushi, K., Yamaguchi, M., Aonuma, Y., Kitano, S. 2003. Species diversity and abundance of freshwater fishes in irrigation ditches around rice fields. Environ Biol Fish 66: 107-121. (in Japanese)

Kawamura, T. 1962. On the names of some Japanese frogs. J Sci Hiroshima Univ Ser B, Div 1, 20: 181-193, pls $1-2$.

Keddy, P. A., Fraser, L. H., Solomeshch, A. I. 2009. Wet and wonderful: The world's largest wetlands are conservation priorities. Biosci 59: 39-51.

Kellner, A., Green, D. M. 1995. Age structure and age at maturity in Flower's toad, Bufo woodhousii fowleri, at their northern range limit. J Herpetol 29: 485-489.

Khonsue, W., Matui, M., Misawa, Y. 2002. Age determination of Daruma pond frog, Rana porosa brevipoda from Japan towards its conservation (Amphibia: Anura). Amphibia-Reptilia 23: 259-268.

Kiesecker, J. M. 2002. Synergism between trematode infection and pesticide exposure: a link to amphibian deformities in nature. Proc Natl Acad Sci USA 99: 9900-9904.

Kiritani, K. 2000. Integrated biodiversity management in paddy fields: Shift of paradigm from IPM toward IBM. Int J Pest Manage 5: 175-183. (in Japanese)

Kiritani, K. 2010. A comprehensive list of organisms associated with paddy ecosystems in Japan (Improved edition). 427pp. NPO Research Institute of Agriculture and Nature. (in Japanese)

Knutson, M., Richardson, W., Reineke, D. M., Gray, B. R., Parmelee, J. R., Weick, S. E. 2004. Agricultural ponds support amphibian population. Ecol Appl 14: 669-684.

Kolozsvary, M. B., Swihart, R. K. 1999. Habitat fragmentation and the distribution of amphibians: patch and landscape correlates in farmland. Can J Zool 77: 1288-1299.
Komaki, S., Kurabayashi, A., Islam, M. M., Tojo, K., Sumida, M. 2012. Distributional Change and Epidemic Introgression in Overlapping Areas of Japanese Pond Frog Species Over 30 Years. Zool Sci 29: 351-358.

Kupferberg, S. J. 1997. Bullfrog (Rana catesbeiana) invasion of a California river: the role of larval competition. Ecology 78: 1736-1751.

Kuramoto, M. 2006. New amphibian classification by Frost et at. (2006). Amphibi Hist 16: 7-12.

Lane, S. J., Fujioka M. 1998. The impacts of changes in irrigation practices on the distribution of foraging egrets and herons (Ardedas) in the rice fields of central Japan. Biol Conserv 83: 221-230.

Lawler, S. P. 2001. Rice fields as temporary wetlands: A review. Israel J Zool 47: 513-528.

Lehtinen, R. M., Galatowitsch, S. M., Tester, J. R. 1999. Consequences of habitat loss and fragmentation for wetland amphibian assemblages. Wetlands 19: 1-12.

Licht, L. E., Grant, K. P. 1997. The effects of ultraviolet radiation on the biology of amphibians. Am Zool 37: 137-145.

Liu, K., Wang, F., Chen, W., Tu, L., Min, M. S., Bis, K., Fu, J. 2010. Rampant historical mitochondrial genome introgression between two species of green pond frogs, Pelophylax nigromaculatus and P. plancy. BMC Evol Biol, 10: 201.

Loman, J., Andersson, G. 2006. Monitoring brown frogs Rana arvalis and Rana temporaria in 120 south Swedish ponds 1989-2005. Mixed trends in different habitats. Biol Conserv. doi:10.1016/j. biocon.2006.09.017.

Maeda, N., Matsui, M. 1999. Frogs and toads of Japan, revised edition. 223pp. Bun-ichi Co., Ltd, Tokyo. (in Japanese)

Marsh, D. M., Trenham, P. C. 2001. Metapopulation dynamics and amphibian conservation. Conserv Biol 15: 40-49.

Matsui, M. 2005. The directions in batrachology. 316pp. Shokabo, Tokyo. (in Japanese)

Matsui, M. 2006. Current status of scientific names in some Japanese amphibians and reptiles. Bull Herpetol Soc Jpn 2006: 117-131.

Mayers, N. 1990. Mass extinction: What can the past tell us about the present and the future? Global Planet Change 82: 175-185. 
Mazerolle, M. J., Desrochers, A. 2005. Landscape resistance to frog movements. Can J Zool 83: 455-464.

Milne, R. J., Bennett, L. P. 2007. Biodiversity and ecological value of conservation lands in agricultural landscapes of southern Ontario, Canada. Landscape Ecol 22: 657-670.

Ministry of Agriculture, Forestry and Fisheries. 2007. MAFF Strategy for the conservation and sustainable use of biological diversity (http://www.maff.go.jp/j/kanbo/ kankyo/seisaku/s_senryaku/pdf/tysei_senryaku.pdf), retrieved on 24 Sep. 2011. (in Japanese)

Ministry of Agriculture, Forestry and Fisheries. 2010. The results of survey of organisms in paddy fields (http:// www.maff.go.jp/j/press/nousin/keityo/pdf/100324-01. pdf), retrieved on 24 Sep. 2011. (in Japanese)

Ministry of Environment. 2001. Report of 5th biodiversity survey on animal distributions: Amphibian and reptile (http://www.biodic.go.jp/reports2/5th/ap_rep/5_ap_rep. pdf), retrieved on Dec. 3 2011. (in Japanese)

Ministry of Environment. 2006. The Red List of threatened species, Japan (http://www.biodic.go.jp/ english/rdb/rdb_f.html), retrieved on 19 April, 2012.

Mizutani, M., Takahashi, N., Hayashi, M. 2005. Effects of covering the small-scale concrete ditch with a wooden lid on inhabitation of Rana japonica. Transac Jap Soc Irrigation Drainage Rural Eng 235: 77-78. (in Japanese)

Morey, S. R. 1990. Microhabitat selection and predation in the Pacific tree frog, Pseudacris regilla. J Hepetol 24: 292-296.

Moriya, K. 1951. On isolating mechanism between two subspecies of the pond frog, Rana nigromaculata. J Sci Hiroshima Univ, Ser B, Div 1: 47-56. (in Japanese)

Moriya, K. 1954. Studies on the five races of the Japanese pond frog, Rana nigromaculata Hallowell. I. Differences in the morphological characters. J Sci Hiroshima Univ ser B, Div 1, 15: 1-21.

Moriya, K. 1956. Regional races of Japanese Blackspotted pond frog and their distributions. BBSJ 16-19: 354-359. (in Japanese)

Moriya, K. 1960. Studies on the five races of the Japanese pond frog, Rana nigromaculata, Hallowell II. Differences in character of development. J Sci Hiroshima Univ Ser B, Div 1, 18: 109-124.

Moriya, K. 1965. Reproductive capability of backcross males between Rana nigromaculata and Rana brevipoda. B Faculty Edu, Okayama Univ 19: 50-63. (in Japanese)

Moriyama, H. 1997. What does it mean to protect paddy fields? 205pp. Rural Culture Association Japan, Tokyo. (in Japanese)

Murakami, H., Osawa, S. 2008. Effects of paddy rice cultivation type on the distribution of Rana nigromaculata and Fejervarya limnocharis. Jpn J Conserv Ecol 13: 187-198. (in Japanese)

Naito, R., Sakai, M., Morimoto, Y. 2012a. Negative effects of deep roadside ditches on Pelophylax porosa brevipoda dispersal and migration in comparison with Hyla japonica in a rice paddy area in Japan. Zool Sci 29: 599-603.

Naito, R., Yamasaki, M., Imanishi, A., Natuhara, Y., Morimoto, Y. 2012b. Effects of water management, connectivity, and surrounding land use on habitat use by frogs in rice paddies in Japan. Zool Sci 29: 577-584.

Nakagawa, S. 1978. Movement of water and irrigation for paddy fields. Kagaku 48: 605-613. (in Japanese)

Natuhara, Y. 2012. Ecosystem services by paddy fields as substitutes of natural wetlands in Japan. Ecol Eng, http://dx.doi.org/10.1016/j.ecoleng.2012.04.026

Nishioka, M., Sumida, M., Ohtani, H. 1992. Differentiation of 70 populations in the Rana nigromaculata group by the methods of electrophoretic analyses. Sci Rep Lab Amphibi Biol Hiroshima Univ 11: $1-70$.

Numazawa, M., Okochi, I. 2006. Longevity in captivity of an endangered Japanese frog of Hiroshima prefecture, Rana porosa brevipoda. Bull Herpetol Soc Jap 2: 97-99.

Ohba, S., Goodwyn, P. J. P. 2009. Life cycle of the water scorpion, Laccotrephes japonensis, in Japanese rice fields and a pond. J Insect Sci 10: 1-10.

Okochi, I., Utsunomiya, T., Utsunomiya, T., Numasawa, M. 1997. Captive breeding and reinforcement to an endangered population of Rana porosa brevipoda Ito (Ranidae:Amphibia). Jpn J Conserv Ecol 2:135-146. (in Japanese)

Osawa, S., Hioki, Y., Matsubayashi, K., Fujiwara, N., Katsuno, T. 2003. The analysis of fauna composition for predicted habitat of amphibians. J Jpn Inst Landsc Archit 66: 327-336. (in Japanese)

Osawa, S., Katsuno, T. 2003. Factors restricting the distribution of frogs in a rural landscape characterized 
by dispersed settlement in Isawa, Iwate prefecture, northeast Japan. J Jpn Inst Landsc Archit 66: 613-616. (in Japanese)

Osawa, S., Katsuno, T. 2005. Distribution pattern of amphibian on rural landscape in the middle reaches of the Oita River, Northeast Kyusyu. J Rural Plann Assoc 68: 563-566. (in Japanese)

Osawa, S., Katsuno, T. 2007. The grassland on levees is the habitat of Rana japonica in the terrace paddy field. $\mathrm{J}$ Rural Plann Assoc 26: 221-226. (in Japanese)

Osawa, S., Kuroda, T., Katsuno, T. 2006. The change of vegetation, fauna of frogs and mousse as small animals, on different management level in step-like paddy fields. J Jpn Inst Landsc Archit 69: 565-570.

Osawa, S., Shimada, M., Katsuno, T. 2005. Environmental factors that regulate the density of Rana porosa porosa on the levees of flatland paddy fields. J Rural Plann Assoc 24: 91-102. (in Japanese)

Ota, H. 2000. Current status of the threatened amphibians and reptiles of Japan. Popul Ecol 42: 5-9.

Pechmann, J. H. K., Wilbur, H. M. 1994. Putting declining amphibian populations in perspective: natural fluctuations and human impacts. Herpetologica 50: 65-84.

Peltzer, P. M., Lajmanovich, R. C., Attademo, A. M., Beltzer, A. H. 2006. Diversity of anurans across agricultural ponds in Argentina. Biodiv Conserv 15: 3499-3513.

Porej, D., Hetherington, T. E. 2005. Designing wetlands for amphibians: the importance of predatory fish and shallow littoral zones in structuring of amphibian communities. Wetl Ecol Manag 13: 445-455.

Ramsar Convention. 2008. Enhancing biodiversity in rice paddies as wetland systems. Ramsar COP10 DR31 (http://www.ramsar.org/pdf/cop10/cop10_dr31_e.pdf), retrieved on 4 June. 2012.

Rannap, R., Lõhmus, A., Briggs, L. 2009. Restoring ponds for amphibians: a success story. Hydrobiologia 634: 87-95.

Räsäsnen, K., Laurila, A., Merilä, J. 2002. Carry-over effects of embryonic acid conditions on development and growth of Rana temporaria tadpoles. Freshwater Biol 47: 19-30.

Raven, P. H. 1990. The politics of preserving biodiversity. BioScience 40: 769-774.
Ricketts, T. H., Daily, G. C., Ehrlich, P. R. 2001. Countryside biogeography of moths in a fragmented landscape: biodiversity in native and agricultural habitats. Conserv Biol 15: 378-388.

Rothermel, B. B., Semlitsch, R. D. 2002. An experimental investigation of landscape resistance of forest versus old-field habitats to emigrating juvenile amphibians. Conserv Biol 16: 1324-1332.

Saijo, H. 2001. Seasonal prevalence and migration of aquatic insects in paddies and an irrigation pond in Shimane Prefecture. Jpn J Ecol 51: 1-11. (in Japanese)

Saitoh, K., Katano, O., Koizumi, A. 1998. Movement and spawning of several freshwater fishes in temporary waters around paddy fields. Jpn J Ecol 38: 35-47. (in Japanese)

Sato, T., Azuma, A. 2003. Frogs abundance and environments of levees relationships around paddy fields in alluvial fan. J Jpn Inst Landsc Archit 67: 519-522. (in Japanese)

Sawahata, T. 2002. Seasonal changes in number of Rana porosa brevipoda killed on the road. Bull Herpetol Soc Jpn 2: 72-74. (in Japanese)

Semlitsch, R. D. 2000. Principles for management of aquatic-breeding amphibians. J Wildlife Manage 3: 615-631.

Semlitsch, R. D. 2002. Critical elements for biologically based recovery plans of aquatic-breeding amphibians. Conserv Biol 16: 619-629.

Serizawa, T. 1983. Reproductive traits of Rana nigromaculata-brevipoda complex in Japan. I Growth and egg laying in Tatsuda and Saya, Aichi prefecture. Jpn J Herpetol 10: 7-19. (in Japanese)

Serizawa, T. 1985. Reproductive traits of the Rana nigromaculata-brevipoda complex in Japan. II. Egglaying of Rana brevipoda brevipoda and $R$. nigromaculata in places dried up in early spring. Jpn J Herpetol 11: 11-19. (in Japanese)

Serizawa, T., Serizawa, S. 1982. Variation in Rana brevipoda in the Western Tokai District. Jap J Herpetol 9: 87-98. (in Japanese)

Shimoyama, R. 1986. Maturity and clutch frequency of females Rana porosa brevipoda in the northern Ina Basin, Nagano Prefecture, Japan. Jpn J Herpetol 11: 167-172.

Shimoyama, R 1996. Sympatric and synchronous breeding 
by two pond frogs, Rana porosa brevipoda and Rana nigromaculata. Jap J Herpetol 16: 87-93.

Shimoyama, R. 2000. Breeding ecology and interspecific relationship in two Japanese pond frogs. Amphibi Hist 4: 1-5. (in Japanese)

Shimoyama, R. 2005. Reproductive behavior of Rana nigromaculata and Rana porosa brevipoda. The directions in batrachology (Matui, M. eds.), 104-114. Shokabo, Tokyo (in Japanese)

Sinsch, U. 1990. Migration and orientation in anuran amphibians. Ethol Ecol Evol 2:65-79.

Smith, G. R., Todd, A., Retting, J. E., Nelson, F. 2003. Microhabitat selection by Northern cricket forgs (Acris crepitans) along a West-central Missouri creek: Field and experimental observations. J Herpetol 37: 383-385.

Smith, K. F., Sax, D. F., Lafferty, K. D. 2006. Evidence for the role of infectious disease in species extinction of frogs. EcoHealth 4: 125-134.

Sparling, D. W., Lowe, T. P. 1996. Metal concentrations of tadpoles in experimental ponds. Environ Pollut 91: 149-159.

Storfer, A. 2003. Amphibian declines: future directions. Diversity Distrib 9:151-163.

Stuart, S. N., Chanson, J. S., Cox, N. A., Young, B. E., Rodrigues, A. S. L, Fischman, D. L., Wallwe, W. 2004. Status and trends of amphibian declines and extinctions worldwide. Science 302: 1783-1786.

Stumpel, A. H. P., ven der Voet, H. 1998. Characterizing the suitability of new ponds for amphibians. Amphibiareptilia 19: 125-142.

Sumida, M., Ishihara, T. 1997. Natural hybridization and introregression between Rana nigromaculata and Rana brevipoda in central Japan. Amphibia-Reptilia 18: 249-257.

Sumida, M., Ogata, M., Kaneda, H., Yonekawa, H. 1998. Evolutionary relationships among Japanese pond frogs inferred from mitochondrial DNA sequences of cytochrome $\mathrm{b}$ and $12 \mathrm{~S}$ ribosomal RNA genes. Genes Genet Syst 73: 121-133.

Sumida, M., Ogata, M., Nishioka, M. 2000. Molecular phylogenetic relationships of pond frogs distributed in the Palearctic region inferred from DNA sequences of mitochondrial $12 \mathrm{~S}$ ribosomal RNA and cytochrome $\mathrm{b}$ genes. Mol Phylogenet Evol 16: 278-285.

Suzuki, K., Okubo, K., Sawahata, T. 2002. The distribution and population density of the threatened species Rana porosa brevipoda and conditions of paddies as frog habitats in the Ina basin, Nagano prefecture, in central Japan. J Jpn Inst Landsc Archit 65: 517-522. (in Japanese)

Tallman, D. A., Luikart, G., Waples, R. S. 2004. The alluring simplicity and complex reality of genetic rescue. Trends Ecol Evol 19: 489-496.

Togane, D., Fukuyama, K., Kuramoto, N. 2005. Size distribution and growth rates of the Tokyo Daruma pond frog, Rana porosa porosa in paddy fields at valley bottoms. Bull Herpetol Soc Jpn 1: 13-22. (in Japanese)

Touchon, J. S., Warkentin, K. M. 2009. Negative synergism of rainfall patterns and predators affects frog egg survival. J Anim Ecol 78: 715- 723.

Tsuji, M., Ushimaru, A., Osawa, T., Mitsuhashi, H. 2011. Paddy-associated frog declines via urbanization: A test of the dispersal-dependent decline hypothesis. Landscape Urban Plan 103: 318-325.

Umematsu, Y., Koga, T., Mitsuhashi, H., Ushimaru, A. 2010. Abandonment and intensified use of agricultural land decrease habitats of rare herbs in semi-natural grassland. Agr Ecosyst Environ 135: 304-309.

Van Buskirk, J. 2005. Local and landscape influence on amphibian occurrence and abundance. Ecology 86: 1936-1947.

Vitt, L. J., Caldwell, J. P., Wilbur, H. M., Smith, D. C. 1990. Amphibians as harbingers of decay. BioScience 40: 418.

Wake, D. B. 1991. Declining Amphibian Populations. Science 253: 860 .

Watabe, K., Senga, Y., Mori, A., Koizumi, N., Takemura, T., Nishida, K. 2012. Population model of Rana japonica crossing agricultural concrete canals: evaluating population conservation by improving the migration routes of frogs. Paddy Water Environ DOI 10.1007/ s10333-012-0313-7.

Wellborn, G. A., Skelly, D. K., Werner, E. E. 1996. Mechanisms creating community structure across a freshwater habitat gradient. Annu Rev Ecol Syst 27: 337-363.

Wilbur, H. M. 1980. Complex life cycles. Annu Rev Ecol Syst11: 67-93.

Wyman, R. L. 1990. What's Happening to the Amphibians. Conserv Biol 4: 350-352. 
Yamazaki, F. 1996. Stories of paddy fields in Japan. 188pp. Rural Culture Association Japan, Tokyo (in Japanese)

Yoshida, M., Yabu, S., Yamada, H. 2007. A research about conservation strategy for frog species at paddy fields. J Jpn Soc Reveget Tech 33: 284-287. (in Japanese)

Zedler, J. B., Kercher, S. 2005. Wetland resources: Status, trends, ecosystem services, and restorability. Annu Rev Environ Resour 30: 39-74.

Zhang, H., Yan, J., Zhang, G., Zhou, K. 2008. Phylogeography and demographic history of Chinese black-spotted frog populations (Pelophylax nigromaculata): evidence for independent refugia expansion and secondary contact. BMC Evol Biol 8:21.

Zug, G. R. 1993. Herpetology: An introductory biology of amphibians and reptiles. 527pp. Academic Press, San Diego. 